\title{
Article
}

\section{Decision Makers for Online Purchases of Fashion Products on Reebonz Online Shopping Sites}

\author{
Fajar Rezeki Ananda Lubis ${ }^{1}$, Rini Anggriani ${ }^{2}$, Dinda Amanda Zuliestiana ${ }^{3}$, Onita Sari Sinaga ${ }^{4}$, Acai Sudirman \\ $4, *$
}

How to cite this paper: Rezeki Ananda Lubis, F., Anggriani, R., Amanda Zuliestiana, D., Sari Sinaga, O., \& Sudirman, A. (2021). Decision Makers for Online Purchases of Fashion Products on Reebonz Online Shopping Sites. Universal Journal of Business and Management, 1(1), 62-71. Retrieved from https://www.scipublications.com/journal/index.php/ujbm/article/view/83

Received: July 10, 2021

Accepted: August 20, 2021

Published: August 21, 2021

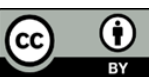

Copyright:@ 2021 by the authors. Submitted for possible open access publication under the terms and conditions of the Creative Commons Attribution (CC BY) license (http://creativecommons.org/licenses /by/4.0/).

\author{
${ }^{1}$ Management Study Program, Universitas Prima Indonesia, Medan, Indonesia \\ ${ }^{2}$ Management Study Program, Universitas Bumigora, Mataram, Indonesia \\ ${ }^{3}$ Faculty of Economics and Business, Universitas Telkom, Bandung, Indonesia \\ ${ }^{4}$ Management Study Program, Sekolah Tinggi Ilmu Ekonomi Sultan Agung, Pematangsiantar, Indonesia \\ *Correspondence: acaivenly@stiesultanagung.ac.id ; Tel: +6282165264931
}

\begin{abstract}
The level of business competition in several online shopping sites for fashion products is currently experiencing quite crucial dynamics. Competitive match will indirectly affect consumer purchasing decisions. This research explores what factors are dominantly influencing the level of product purchase decisions on online shopping sites in terms of product variety, price, brand image and promotion aspects. This research design uses a quantitative research design. Determination of the sample in this study using the convenience sampling method with a total of 110 respondents. Data collection uses a questionnaire distributed online during the period from May to June 2021. This study concludes that product variations and brand image have a positive and significant influence on purchasing decisions. Then for the effect of price and promotion on purchasing decisions obtained a positive but not significant impact. This study confirms the importance of paying attention to aspects of pricing and product promotion strategies on the Reebonz online shopping site.
\end{abstract}

Keywords: Product Variation; Price; Brand Image; Promotion; Purchasing Decisions

\section{Introduction}

As a pioneer in the branded product business, the Reebonz shopping site presents various advantages that strengthen its position as the new luxury ecosystem. The founders of Reebonz saw the market growth so fast, that innovative innovation efforts were needed. This condition is crucial for Reebonz as a pioneer in the luxury product business. Through the online ecosystem, Reebonz provides various conveniences for its customers to access world-renowned branded products through multiple features, one of which is Reebonz Closets, an application that connects fashion lovers to sell and buy preloved goods from world-renowned designers. On the other hand, Reebonz Marketplace also offers members access to hundreds of collections of rare branded products from boutique owners and vintage curators; and Reebonz Space, an offline version of Reebonz, already present in several countries such as Singapore, Australia and Thailand. To continue to exist among consumers, it is necessary to have a concrete marketing strategy to build and grow purchasing decisions on the Reebonz online shopping site. The steps that can be taken include providing various products according to consumer tastes, setting standard prices, building a brand image and preparing a credible promotional strategy. To continue to exist among consumers, it is necessary to have a concrete marketing strategy to develop and grow purchasing decisions on the Reebonz online shopping site. The steps that can be taken include providing various products according to consumer tastes, setting standard prices, building a brand image and preparing a credible promotional strategy [1]. To continue to exist among consumers, it is necessary 
to have a concrete marketing strategy to develop and grow purchasing decisions on the Reebonz online shopping site. The steps that can be taken include providing various products according to consumer tastes, setting standard prices, building a brand image and preparing a credible promotional strategy [2]

The ability to create many product variations to meet every demand is one factor to compete in a competitive market [3]. A variety of products based on size, price, appearance or other characteristics as distinguishing elements reflects product variations [4]. Product variety or product diversity is nothing new in marketing, where business actors and marketers widely use this strategy to complete their marketing mix [5]. Product variation as a separate expert in a brand or product can be distinguished based on size, price, appearance or characteristics. According to [6], product variations are suitable to be chosen if the company intends to take advantage of product flexibility as a competitive strategy with manufacturers such as standard products. Therefore, the essence of a variety of products available on the Reebonz online shopping site is the basis for consumers to take actions that lead to the stigma of making purchases or vice versa. Research results [7], with a research study on purchasing decisions on Zalora.co.id E-commerce consumers, concluded that product variations have a significant effect on purchasing decisionss. The same thing was also conveyed [8], with a focus on the study of purchasing decisionss in terms of smartphone product variations, conveyed that product variations also encouraged purchasing decisionss.

In addition to the product variation factor, the marketing mix element known as price is one of the crucial factors influencing a consumer's purchase decision [9]. On the other hand, price is the amount of money charged for a product or service or the amount of value paid by consumers to benefit from or have or use the service [10]. According to [11], price can be defined as the amount of money charged for a product or service or in another sense defined as the amount of value that consumers exchange for the benefit of owning and using the product or service that allows the company to earn a fair profit by being paid for customer value [12]. This indicates the crucial role of price for consumers to determine their buying attitude. Research result [13] finds facts that lead to a significant price involvement in consumer purchasing decisions. On the other hand, the study results [14] focused on online purchasing decision research on E-Commerce Lazada concluded that prices have a significant contribution to the highs and lows of purchasing decisions.

The existence of a brand image attached to a product is very important for the product's sustainability. Every company has an image, whether consciously or not, has been linked to the company [15]. Not a few goods or services produced by the company so strong image in the minds of consumers. Thus the brand image is one of the most critical assets of a company or organization that should be continuously built and maintained [16]. A good image is a powerful tool, not only to attract consumers to choose a product or company, but also to improve consumer buying attitudes. Companies must develop brands to give a positive impression in the minds of consumers [17]. A positive image will ultimately make customers loyal and willing to repurchase the product in the future. This statement is supported by research results [18], which states that a wellconstructed brand image influences consumer purchasing decisions. The same thing was said [19], which confirms that its brand image influences the purchase decision.

No less important factor to drive purchasing decisions is the marketing mix element by the name of promotion. In doing business, trading, or selling services online, every business person needs to promote to consumers in several ways [20]. This promotion aims to introduce the products and services that you sell to attract consumers' attention [21]. The role of promotion is considered quite important because it can affect the product's existence in the market. The urgency of doing promotions to recognize products through a digital marketing system can efficiently and effectively promote products. In addition, it not only provides information about product characteristics, but can also provide education to consumers, such as benefits and advantages that cannot be found in other 
products [22]. Research result [23] with the substance of research on purchasing decisions in fashion stores on the social network Facebook stated that the role of promotion is very dominant in determining consumer purchasing decisions. The same thing was also conveyed [24] with the focus of research on purchasing decisions for fashion products at Lazada on students in Jakarta, stated that promotion to purchasing decisions was positive and significant.

The importance of the product variety factor in selling online also invites the attention of business people to increase the existence of their products. We believe that the large variety of products is considered to make the brand more preferred by consumers. The wide distribution and convenience offered by the product also affect consumer choice. On the other hand, the importance of the brand image of a product helps the growth of the product brand. A brand needs to be bought more and more often to get business growth. Therefore, the brand must be relevant to the changing needs of consumers. Furthermore, promotion is crucial to be carried out by various business circles, both small-scale and large-scale businesses. Although promotion is an important thing in business, many business people think that promotion is not essential or even too confident in their business that they don't need to carry out activities related to promotion. The urgency of this research is to examine the contribution of product variations, price, brand image and promotion to the purchasing decisions of fashion products on the online shopping site Reebonz. This research is expected to provide additional information for Reebonz online shopping site developers and consumers to synergize with each other to build reputation and encourage the growth of fashion product sales on the Reebonz online shopping site. but there are still many business people who think promotion is not essential or even too confident in their business so they don't need to carry out activities related to promotion. The urgency of this research is to examine the contribution of product variations, price, brand image and promotion to the purchasing decisions of fashion products on the online shopping site Reebonz. This research is expected to provide additional information for Reebonz online shopping site developers and consumers to synergize with each other to build reputation and encourage the growth of fashion product sales on the Reebonz online shopping site. but there are still many business people who think promotion is not essential or even too confident in their business so they don't need to carry out activities related to promotion. The urgency of this research is to examine the contribution of product variations, price, brand image and promotion to the purchasing decisions of fashion products on the online shopping site Reebonz. This research is expected to provide additional information for Reebonz online shopping site developers and consumers to synergize with each other to build reputation and encourage the growth of fashion product sales on the Reebonz online shopping site.

\section{Materials and Methods}

Quantitative research design with associative approach is used in this study. The data used in this study used primary data by collecting through online questionnaires. The research population is consumers who buy fashion products on the online shopping site Reebonz. Due to the unknown number of the population, the sample was taken using a convenience sampling technique. According to [25], if the number of the population is not known ideally the size of the representative respondents depends on the sum of all indicators in the variable multiplied by $5-10$. This study has 22 indicators, so the minimum number of respondents for this study is $22 \times 5=110$. Therefore, the number of respondents who were taken for this study after being rounded up involved 110 respondents. Testing the questionnaire data using a validity test, where if rcount 0.3 with $95 \%$ significance it is declared valid [26] and the rebiability test, where a variable is said to be reliable, if it has a Cronbach alpha value $>0.60$ [27]. Furthermore, multiple regression tests were carried out, hypothesis testing with simultaneous and partial methods and correlation tests with the coefficient of determination. 


\section{Results}

\subsection{Characteristics of Respondents}

Table 1. General Profile of Respondents

\begin{tabular}{|c|c|c|c|}
\hline Category & Details & Amount & $\begin{array}{c}\text { Percentage } \\
\mathbf{( \% )}\end{array}$ \\
\hline Gender & Men & 35 & 42.79 \\
& woman & 75 & 57.21 \\
\hline \multirow{3}{*}{ Age (years) } & $20-29$ & 46 & 17.67 \\
& $30-39$ & 40 & 44.19 \\
& $40-49$ & 24 & 24.65 \\
\hline & Employee & & \\
Profession & Entrepreneur & & \\
& Government & & \\
employees & & \\
Income (in Rupiah) per & Others & & \\
mont & $<1$ million & & \\
& $5-5$ million & & \\
& $>10$ million & & \\
\hline \multirow{2}{*}{ Purchase frequency (in } & $<1$ & 21 & 5.58 \\
times) & $1-5$ & 49 & 7.44 \\
& $6-10$ & 40 & 20.47 \\
\hline
\end{tabular}

\subsection{Validity and Reliability Test}

Table 2. Validity Test Results

\begin{tabular}{|c|c|c|c|}
\hline Variable & $\begin{array}{c}\text { Corrected item- To- } \\
\text { tal } \\
\text { correlation }\end{array}$ & N of Items & $\begin{array}{c}\text { Test re- } \\
\text { sults }\end{array}$ \\
\hline $\begin{array}{c}\text { Product } \\
\text { Variations }\end{array}$ & 0.452 & 4 & Valid \\
\hline Price & 0.516 & 5 & Valid \\
\hline Brand Image & 0.527 & 5 & Valid \\
\hline Promotion & 0.570 & 3 & Valid \\
\hline $\begin{array}{c}\text { Purchase } \\
\text { Decisions }\end{array}$ & 0.581 & 5 & Valid \\
\hline
\end{tabular}

Based on the validity test of table 1 above, it is concluded that all indicators in the study have a value above 0.30 , therefore the measurement items used in this research are valid. Next, a reliability experiment is carried out which is used to measure the measurement items on the questionnaire items that describe the indicators of the variables. A questionnaire is reliable if a person's response to a question does not change or is normal from time to time. 
Table 3. Reliability Test Results

\begin{tabular}{|c|c|c|c|}
\hline Variable & Cronbach's Alpha & $\begin{array}{c}\text { N of } \\
\text { Items }\end{array}$ & $\begin{array}{c}\text { Test re- } \\
\text { sults }\end{array}$ \\
\hline $\begin{array}{c}\text { Product } \\
\text { Variations }\end{array}$ & 0.732 & 4 & Reliable \\
\hline Price & 0.710 & 5 & Reliable \\
\hline Brand Image & 0.715 & 5 & Reliable \\
\hline Promotion & 0.702 & 3 & Reliable \\
\hline $\begin{array}{c}\text { Purchase } \\
\text { Decisions }\end{array}$ & 0.709 & 5 & Reliable \\
\hline
\end{tabular}

Based on the results of the reliability experiments shown in table 2 above, it proves that all indicators have a Cronbach alpha value for each instrument $>0.70$, so it can be concluded that all tools used are reliable.

\subsection{Multiple Regression Test}

Table 4. Multiple Regression Test Results

\begin{tabular}{|c|c|c|c|c|c|c|}
\hline & \multirow[t]{2}{*}{ Model } & \multicolumn{2}{|c|}{$\begin{array}{c}\text { Unstandardized } \\
\text { Coefficients }\end{array}$} & \multirow{2}{*}{$\begin{array}{c}\text { Standardized } \\
\text { Coefficients }\end{array}$} & \multirow[t]{2}{*}{ tcount } & \multirow[t]{2}{*}{ Sig. } \\
\hline & & $\mathrm{B}$ & Std. Error & & & \\
\hline & (Constant) & 6,969 & 1,807 & & 3,857 & .000 \\
\hline 1 & $\begin{array}{c}\text { Product } \\
\text { Variations }\end{array}$ & ,396 & 0.079 & .418 & 5.023 & .000 \\
\hline & Price & ,095 & 0.080 & .105 & 1.179 & .241 \\
\hline & Brand Image & 152 & 0.070 & .205 & 2.157 & .033 \\
\hline & Promotion & , 125 & ,110 & .108 & 1.133 & .260 \\
\hline & a. $\mathrm{D}$ & de & able: & den & & \\
\hline
\end{tabular}

The results of the multiple linear regression above, obtained the equation model: = $6.969+0.396 \mathrm{X} 1+0.095 \times 2+0.152 \times 3+0.125 \mathrm{X} 4$, which means that product variations, price, brand image and promotion have a positive effect on purchasing decisions. Based on these equations, it can be interpreted as follows:

1. The constant value of 6.969 can be interpreted if product variations, price, brand image and promotion are considered zero, then the value of purchasing decisions will be in the range of 6.969 values.

2. The value of the beta coefficient on the product variations variable is 0.396 , which means that every change in the product variations variable by one unit will result in a change in purchasing decisions of 0.396 units assuming the other variables are constant.

3. The value of the beta coefficient on the price variable is 0.095 , which means that every change in the price variable by one unit will result in a change in purchasing decisions of 0.095 units assuming that the other variables are at a constant value.

4. The value of the beta coefficient on the brand image variable is 0.152 , which means that every change in the brand image variable by one unit will result in a change in 
purchasing decisions of 0.152 units assuming that the other variables are at a constant value.

5. The value of the beta coefficient on the promotion variable is 0.125 , which means that every change in the promotion variable by one unit will result in a change in purchasing decisions of 0.125 units assuming that the other variables are at a constant value.

\subsection{Simultaneous and Partial Hypothesis Testing}

To examine the variable binding simultaneously, experiment $\mathrm{F}$ is used. Simultaneous hypothesis testing is tried to identify whether the product variations, price, brand image and promotion that are tried to influence purchasing decisions simultaneously.

Table 5. Simultaneous Test Results

\begin{tabular}{|c|c|c|c|c|c|}
\hline \multicolumn{2}{|c|}{ Model } & Sum of Squares & df & F & Sig. \\
\hline \multirow{4}{*}{1} & Regression & 89,207 & 4 & $\mathbf{1 6 , 4 5 8}$ & $\mathbf{. 0 0 0 b}$ \\
\cline { 2 - 2 } & Residual & 142,284 & 105 & & \\
\cline { 2 - 2 } & Total & 231.491 & 109 & & \\
\hline
\end{tabular}

Based on the results of the simultaneous test analysis in table 5, the Fcount value is $16,458>$ from Ftable with $(0.05 ; 4$ vs 116) of 2.46 or with a significant $0.000<0.05$, it can be interpreted as product variations, price, brand image and promotion that are tried to influence purchasing decisions in a simultaneously acceptable way. Furthermore, a partial test is carried out that aims to determine the relationship between product variations, price, brand image, and promotion variables that partially influence purchasing decisions. Based on the results of data analysis in table 4, the results of the t-test in this study are as follows:

1. The product has a significant level of 0.0000 .05 , meaning that product variations significantly affect purchasing decisions.

2. The price obtained a significant level of $0.241>0.05$, meaning that the price has no significant effect on purchasing decisions

3. Place obtained a significant level of 0.0330 .05 , meaning that brand image significantly affects purchasing decisions.

4. Promotion obtained a significant level of 0.2600 .05 , meaning that promotion has no significant effect on purchasing decisions.

\subsection{Coefficient of Determination Test}

The coefficient of determination is done to measure how far the ability of a model to explain the variation of the dependent variable. The results of the determination test in this study can be explained in Table 6 below:

Table 6. Coefficient of Determination Test Results

\begin{tabular}{|c|c|c|c|c|}
\hline Model & $\mathbf{R}$ & R Square & $\begin{array}{c}\text { Adjusted R } \\
\text { Square }\end{array}$ & $\begin{array}{c}\text { Std. Error of the } \\
\text { Estimate }\end{array}$ \\
\hline 1 & $.621 \mathrm{a}$ & .385 & .362 & 1.164 \\
\hline
\end{tabular}

Based on the results of data analysis in table 6 above, the coefficient of determination value is 0.385 , which means that product variations can explain the high and low purchasing decisions of $38.5 \%$, price, brand image and promotion, while factors can explain the remaining $61.5 \%$ others not discussed in this study.

\section{Discussion}


Based on the results of partial hypothesis testing (H1), product variations significantly affect purchasing decisions. These results prove that the condition of product variation is an essential thing in determining the selection of a product by consumers. Consumers will prefer and like other similar products that can meet their needs and desires [28]. The variety of products available on the Reebonz online shopping site is advantageous for consumers as they can choose from various alternatives. The existence of product diversity will provide flexibility for consumers in determining the choice of products to be purchased to meet needs and complete needs. Therefore, the increasing number of product variations offered can encourage consumers to carry out a continuous purchasing decision process [29].

Based on partial hypothesis testing $(\mathrm{H} 2)$ results, the price has no significant effect on purchasing decisions. If the price offered by the company is not following customer expectations, the customer will decide to postpone the purchase of a product. Although the variety of products available on the Reebonz online shopping site is very diverse, if the price offered is not following consumer expectations, it will create a stigma not to buy the product [30]. The price labeled on each product on the online shopping site Reebonz is fixed, so consumers cannot exercise bargaining power on the product. Customers will make continuous purchases [31]. Therefore, it can be concluded that the price affects purchasing decisions.

Based on the results of partial hypothesis testing (H3), brand image significantly affects purchasing decisions. The consumer's interpretation of the advantages of attributes, uses, situations, users and characteristics of the maker of the product or brand allows consumers to make purchasing decisions about the brand. A strong growing brand image can win business competition because it offers attractiveness to consumers and provides product differentiation [32]. This is why the products offered on the online shopping site Reebonz are trendy among buyers, especially those who are mostly millennial buyers. On the other hand, a brand that grows big and strong can easily expand its business volume. Because the market will be easier to recognize and accept new products or variants launched by the brand [33]. With a strong brand image, it will undoubtedly encourage high purchase intensity online.

Based on the results of partial hypothesis testing (H4), promotion has no significant effect on purchasing decisions. Promotion is the most important activity that plays an active role in introducing, informing, and reminding consumers of the benefits of a product to encourage consumers to buy the promoted product. Promotion refers to the various activities the company undertakes to communicate the goodness of its products and persuade customers and consumers to buy the product [34]. The results of this study illustrate that consumer purchasing decisions on the online shopping site Reebonz are influenced by promotional factors and product variations and strong brand image, which also builds a positive stigma on consumer attitudes to make purchases. On the other hand, the online shopping site Reebonz also carries out promotions on newly released products that are not yet widely known to consumers to get the attention of new consumers so that they intend to purchase these products [35].

\section{Conclusions}

This study suggests that of the four hypotheses developed, only two hypotheses can be accepted. For the influence of product variations and brand image obtained a positive and significant effect on purchasing decisions. The existence of product variations is an attempt to create a distinct advantage over other products. In business, excellence can indeed be viewed from many aspects, such as appearance, benefits, lower prices, etc. Products that are different from other products can be superior because they have advantages in appearance, brand strength, and more appealing views. Usually the same product will be considered typical once a product with this differentiation value appears. 
Furthermore, for the effect of price and promotion on purchasing decisions, the results are not significant.

\section{Author Contributions:}

Fajar Rezeki Ananda, as the first author to carry out the research activity, Rini Anggriani, Dinda Amanda Zuliestiana and Onita Sari Sinaga as the second to fourth writer who has done the editing of the manuscript and review of the article, Acai Sudirman as the corresponding author who has submitted the article, edited the manuscript and carry out the review process.

Funding: This research received no external funding

Data Availability Statement: Already mentioned in appropriate sections

Acknowledgments: This paper is dedicated to Almighty GODwho bestows HISblessings in all walks of my life

Conflicts of Interest: No conflict of interest

\section{References}

[1] I. Ayesha, F. Redjeki, A. Sudirman, A. Leonardo, and D. F. Aslam, “Behavior of Female Entrepreneurs in Tempe Small Micro Enterprises in Tasikmalaya Regency , West Java as Proof of Gender Equality Against AEC," in Proceedings of the 2nd Annual Conference on Blended Learning, Educational Technology and Innovation (ACBLETI 2020), 2021, vol. 560, no. Acbleti 2020, pp. 124130.

[2] A. Afwa, N. D. Djajasinga, A. Sudirman, A. L. Sari, and N. M. Adnan, "Raising the Tourism Industry as an Economic Driver," in Proceedings of the 2nd Annual Conference on Blended Learning, Educational Technology and Innovation (ACBLETI 2020) Raising, 2021, vol. 560, no. Acbleti 2020, pp. 118-123.

[3] A. A. Purwati, J. J. Siahaan, and Z. Hamzah, “Analisis Pengaruh Iklan, Harga dan Variasi Produk terhadap Keputusan Pembelian di Toko Rumah Mebel Pekanbaru," J. Ekon. KIAT, vol. 30, no. 1, p. 20, 2019, doi: 10.25299/kiat.2019.vol30(1).3870.

[4] Peter, Zamhari, and L. Miranda, "Analisis Pengaruh Variasi Produk, Harga dan Lokasi terhadap Keputusan Pembelian Produk Kentucky Fried Chicken (KFC) Cabang Bangka Trade Center Pangkalpinang," J. Ilm. Progresif Manaj. Bisnis, vol. 26, no. 2, pp. 1-13, 2018.

[5] P. Kotler and K. L. Keller, Manajemen Pemasaran, Edisi 2. Jakarta: Erlangga, 2009.

[6] F. Tjiptono, Strategi Pemasaran, Edisi 3. Yogyakarta: Andi Offset, 2008.

[7] D. F. Pradwika and S. P. Hadi, “Pengaruh Promosi Kreatif Dan Variasi Produk Terhadap Keputusan Pembelian Pada Konsumen E-Commerce Zalora.co.id (Studi Kasus Pada Konsumen Di Kota Jakarta),” Diponegoro J. Soc. Polit., vol. 7, no. 5, pp. 1-8, 2018.

[8] I. Nurrahman and D. H. Utama, "Pengaruh Variasi Produk Terhadap Keputusan Pembelian (Survei Pada Pembeli Smartphone Nokia Series X Di Bec Bandung)," J. Bus. Manag. Enterpreneursh. Educ., vol. 1, no. 1, pp. 54-63, 2016, doi: 10.17509/jbme.v1i1.2278.

[9] Albari and I. Safitri, “The Influence of Product Price on Consumers' Purchasing Decisions," Rev. Integr. Bus. Econ. Res., vol. 7, no. 2, pp. 328-337, 2018.

[10] A. Sudirman, E. Efendi, and S. Harini, "Kontribusi harga dan kepercayaan konsumen untuk membentuk kepuasan pengguna transportasi berbasis aplikasi," J. Bus. Bank., vol. 9, no. 2, pp. 323-335, 2020, doi: 10.14414/jbb.v9i2.2078.

[11] P. Kotler and G. Amstrong, Principles Of Marketing, 14 Edition. Brunel University, UK: Pearson Education, 2014.

[12] M. Pradana and A. Wisnu, “The Impacts of Threat Emotions and Price on Indonesians' Smartphone Purchasing Decisions," J. Asian Financ. Econ. Bus., vol. 8, no. 2, pp. 1017-1023, 2021, doi: 10.13106/jafeb.2021.vol8.no2.1017.

[13] P. Sopiyan, "Pengaruh Strategi Harga Dan Visual Merchandising Terhadap Keputusan Pembelian Online," J. Inspirasi Bisnis dan Manaj., vol. 3, no. 2, pp. 193-205, 2019. 
[14] A. Launtu, "The Effect of Price and Product Quality on Online Purchasing Decisions: Empirical Study in Lazada," J. Manaj. Bisnis, vol. 8, no. 1, pp. 122-132, 2021, doi: 10.33096/jmb.v8i1.691.

[15] A. Sudirman, F. Halim, and R. J. Pinem, “Kepercayaan Sebagai Pemediasi Dampak Citra Merek dan Harga Terhadap Kepuasan Konsumen Gojek," J. Pemasar. Kompetitif, vol. 3, no. 3, pp. 66-76, 2020.

[16] B. Foster, "Impact of Brand Image on Purchasing Decision on Mineral Water Product 'Amidis' (Case Study on Bintang Trading Company)," Am. Res. J. Humanit. Soc. Sci., vol. 2, no. 1, pp. 1-12, 2016, doi: 10.21694/2378-7031.16023.

[17] J. Jasmani and D. Sunarsi, “The Influence of Product Mix, Promotion Mix and Brand Image on Consumer Purchasing Decisions of Sari Roti Products in South Tangerang," PINISI Discret. Rev., vol. 3, no. 2, pp. 165-174, 2020, doi: 10.26858/pdr.v1i1.13409.

[18] L. E. Saputri and A. Utomo, "Pengaruh Brand Image, Kualitas Produk, Dan Harga Terhadap Keputusan Pembelian Sepatu Converse Di Surakarta," Excell. J. Manajemen, Bisnis dan Pendidik., vol. 8, no. 1, pp. 92-103, 2021.

[19] N. Arianty and A. Andira, "Pengaruh Brand Awareness dan Brand Image Terhadap Keputusan Pembelian," Manag. Anal. J., vol. 4, no. 1, pp. 39-50, 2021.

[20] A. Sudirman, F. Halim, G. E. Pakpahan, and Sherly, “Faktor-Faktor Yang Mendorong Minat Beli Smartphone Merek OPPO Dalam Kondisi Pandemi Covid 19," in Seminar Nasional Manajemen, Ekonomi dan Akuntansi, 2020, no. September, pp. 1-11.

[21] E. D. S. Tarigan, H. Sabrina, and Y. Syahputri, “The Influence of Lifestyle and Sales Promotion on Online Purchase Decisions for Home-Cooked Culinary during COVID-19 in Medan City , Indonesia," Int. J. Res. Rev., vol. 7, no. 10, pp. 140-144, 2020, [Online]. Available: www.ijrrjournal.com.

[22] V. Yudhistira and F. D. Patrikha, "Pengaruh Promosi Penjualan Dan Brand Ambassador Terhadap Keputusan Pembelian Dengan Variabel Kepercayaan Sebagai Mediator (Studi Pada Produk Fashion Online Di Surabaya)," J. Pendidik. Tata Niaga, vol. 9, no. 2, pp. 1237-1243, 2021.

[23] E. Verina, E. Yulianto, and W. A. Latief, “Faktor-Faktor Yang Mempengaruhi Keputusan Pembelian Pada Toko Fashion Di Jejaring Sosial Facebook (Survei Pada Konsumen Toko Fashion Di Jejaring Sosial Facebook Yang Berlokasi Di Indonesia)," J. Adm. Bisnis, vol. 10, no. 1, pp. 1-10, 2014.

[24] A. R. Utami, “Faktor Yang Mempengaruhi Keputusan Pembelian Produk Fashion Di Lazada Pada Mahasiswa Di Jakarta,” J. Ind. Kreat. dan Kewirausahaan, vol. 1, no. 2, pp. 83-90, 2018, doi: 10.36441/kewirausahaan.v1i2.115.

[25] J. F. Hair, Multivariat Data Analysis 7th Edition. New Jersey: Pearson Prentice Hall, 2014.

[26] Sugiyono, Metode Penelitian Kuantitatif Kualitatif dan RED. Bandung: Alfabeta, 2017.

[27] K. S. Taber, “The Use of Cronbach's Alpha When Developing and Reporting Research Instruments in Science Education," Res. Sci. Educ., vol. 48, no. 6, pp. 1273-1296, 2018, doi: 10.1007/s11165-016-9602-2.

[28] S. Setyawan, S. N. S, and A. Prativi, "The Effect of Promo Price and Product Variation on Purchasing Decision at Grabfood, OVO Payment as an Intervening Variables," in International Conference on Economics, Management, and Accounting, 2021, vol. 2021.

[29] M. H. Ma'ruf, “The Influence of Product Variations, Prices and Sales Promotions on Consumer Decisions in Buying Mitsubishi Cars in Surakarta," Int. J. Econ. Bus. Account. Res., vol. 1, no. 01, pp. 48-56, 2017, doi: 10.29040/ijebar.v1i01.355.

[30] A. Z. Putri and I. R. Permatasari, "Pengaruh Gaya Hidup dan Harga terhadap Keputusan Pembelian Produk Moslem Fashion di Elzatta Kawi Malang," J. Apl. Bisnis, vol. 4, no. 1, pp. 225-229, 2018, [Online]. Available: file:///C:/Users/BC/Downloads/ISSN GH ke KP signifikan.pdf.

[31] F. A. Zaenal, Ramlawati, and Suriyanti, “Pengaruh Pemasaran Online, Harga, Pelayanan Dan Etika Bisnis Terhadap Keputusan Pembelian Produk," YUME J. Manag., vol. 1, no. 2, pp. 222-232, 2018.

[32] F. Wang and E. S. Hariandja, “The Influence Of Brand Ambassador On Brand Image And Consumer Purchasing Decision: A Case Of Tous Les Jours In Indonesia," in International Conference od Enterpreneurship, 2016, pp. 292-306. 
[33] I. D. Nugroho and S. Sarah, "Pengaruh Brand Image Dan Celebrity Endorser Terhadap Keputusan Pembelian (Studi Pada Konsumen Busana Muslim Merek Maliqa)," J. Indones. Membangun, vol. 20, no. 1, pp. 113-126, 2021.

[34] D. I. Permana, "Pengaruh Promosi Terhadap Keputusan Pembelian Produk Lantai Kayu Dan Pintu Pt.Piji Di Jawa Timur," PERFORMA J. Manaj. dan Start-Up Bisnis, vol. 2, no. 1, p. 269393, 2017, doi: 10.35797/jab.0.0.2017.18378.

[35] M. Y. Siregar, W. Weny, and E. Yuliawan, “The Influence of Promotion Strategies through Social Media on Purchasing Decisions of Oriflame Products on Students of STIE Mikroskil Medan," Budapest Int. Res. Critics Institute-Journal, vol. 3, no. 3, pp. 18381846, 2020, [Online]. Available: http://bircu-journal.com/index.php/birci/article/view/1116. 